\title{
Ownership Concentration, Dividend Policy and Firm Performance in Pakistan
}

\author{
Sadia Murtaza* \\ Department of Business Administration \\ National College Of Business Administration \& Economics, Lahore, Pakistan \\ Amel Aguir \\ Department of Accounting and Finance, ISG, Universite of Sousse, Tunisia
}

\begin{abstract}
Data is drawing from a sample of Chemical firms listed at Karachi Stock Exchange of Pakistan over the period 2002-2017, this paper investigates the relationship between ownership concentration and dividend policy on firm financial performance. Using panel data analysis, the evidence is found to support the assumption of a significant relationship between ownership concentration and dividend policy on firm financial performance. The findings reveal that ownership concentration has a significant positive association with firm financial performance. This stated that larger shareholders can attribute to the alignment of managerial incentives with shareholder interests. They also monitor the team very effectively and efficiently. Dividend policy has a significant positive relationship with ROA. Leverage and Tangibility have a significant negative relationship with financial performance. Board size also has a significant positive impact on firm performance. These results potentially can be relevant for policymakers and academic research.
\end{abstract}

Keywords: Firm's Performance, Ownership Concentration, Dividend Policy, Chemical Sector, Pakistan

DOI: $10.7176 / \mathrm{RJFA} / 10-21-04$

Publication date: November $30^{\text {th }} 2019$

\section{1-Introduction}

Firm ownership and management decisions are the primary sources of corporate governance. The mechanism of corporate governance is considered an important element in controlling and monitoring the firm operations in good and better way(Aslam, Haron, \& Tahir, 2019) it also can increase the firm performance (Bhagat \& Bolton, 2008) and firm valuation (Bebchuk, Cohen, \& Ferrell, 2008; Cuñat, Gine, \& Guadalupe, 2012; Gompers, Ishii, $\&$ Metrick, 2003).

The code of corporate governance is an important element in the developing economies. Such as, the code of corporate governance of Pakistan is conducted by the Security and Exchange Commission of Pakistan (SECP) in March 2002 (Kazi, Arain, \& Sahetiya, 2018) and it is stated that ownership structure plays an important role in firm performance (Shah, Xiao, \& Quresh, 2019). Basically, the ownership structure and firm performance are related to agency theory (Jensen \& Meckling, 1976) which resolve the agency issues among managers and shareholders.

From the past years, corporate governance has secured a great interest in the field of finance (Fu, 2019) and started from the concept of agency theory (Holmstrom, 1979; Ross, 1973). Many different studies have explained that good mechanism of corporate governance can increase the firm valuation and firm performance (Bhagat \& Bolton, 2008; Cremers \& Ferrell, 2014; Cuñat et al., 2012; Giroud \& Mueller, 2011). Different studies have categorized the corporate governance structure into internal and external governance (Baber, Liang, \& Zhu, 2012; Gillan, 2006; Weir, Laing, \& McKnight, 2002). The internal corporate governance consists of the characteristics of the board of directors, board compensation and ownership structure (Jensen, 1993; Jensen \& Meckling, 1976; Yermack, 1996). The external mechanism of corporate governance is concerned with the market rules and regulations, product and services, market competitors and investors control (Jensen, 1986; La Porta, Lopez-de-Silanes, Shleifer, \& Vishny, 1997).

In this study, we plan to take into account, not only the characteristics of the shareholding, but also the dividend policy in Pakistan nonfinancial companies. In fact, managers and shareholders are interested in such decision because managers consider the dividend as a positive indicator of their performance, and shareholders consider it as an indicator for their investment worthiness and consequently enables them to make the rational decisions concerning buying, holding, or selling shares. In this regard (Sáez \& Gutiérrez, 2015) argued that dividend policy is one of the most important factors of determining the firms'value, and consequently firm performance.

We notice that the Asian socio-economic and behavioral peculiarities and institutional settings are different from Western World and studies conducted in Western World have limited implications for Asian countries (Sun, Zhao, \& Yang, 2010; Van Essen, van Oosterhout, \& Carney, 2012). While there is some important evidence on the relationship between ownership concentration, dividend policy on firm performance from other Asian 
countries, the Pakistani context is peculiar for two reasons. First, concentrated and family ownership (presence of large shareholders), on one hand, is more common in Pakistan than, for instance, in Japon and Korea. Similarly, while Chinese companies have more ownership concentration than in Pakistani companies, the nature of ownership concentration is different as the state usually holds high stakes in large companies (Bryson, Forth, \& Zhou, 2014). On the other hand, concentrated ownership in Pakistan is maintained by nongovernment shareholders. No government ownership concentration makes companies like private-owned companies which may have different implications on the firm's performance. Second, we can also observe the legal and political environment in Pakistan which is weaker and the overall governance is poor . Besides, we remark that government effectiveness index and regulatory quality index estimated by World Bank remained negative in the last decade or so.

Our study contributes to the extant literature in a number of ways. In fact, two main reasons motivated the conduction of this study: first, the empirical significance of these studies remains largely unknown especially in terms of the relationship between ownership concentration, dividend payout and firm performance. There are numerous researches have been carried out to identify the unique characteristics of a firm and how it enhances dividend policy (Al-Nawaiseh, 2013; Warrad, Abed, Khriasat, \& Al-Sheikh, 2012). These studies investigated the impact of ownership structure on dividend policy in the industrial and the service sectors. Moreover, some other current studies examined how ownership concentration affects dividend payout, and ultimately firm performance, such as in Malaysia context (Ting, Kweh, \& Somosundaram, 2017). Dividend paying firms enhance firm performance. A key contribution of this study is that it sheds additional light on the inconclusive issues regarding the effects of ownership concentration and dividend policy on firm's performance in the chemical sector, which is still unexplored in an emerging market like Pakistan. Second, other contributions of this paper are as follows. Our study considers persistence and adjustment by using panel data analysis.However, this study is conducted to fill the research gap on examining the relationship between ownership concentration, dividend policy and organizational performance in the emerging market of Pakistan. Rest of the article is organized as follows: Literature review and hypotheses development are presented fluently in Section II. After that, Section III describes data and methodological procedures. Then, Section IV provides empirical results while conclusions are presented lastly in Section V.

\section{2-Literature Review and Hypothesis Development \\ 2.1- Ownership Concentration and Firm Performance}

The central premise of arguments regarding the ownership concentration and firm performance association is the potential trade-off between two effects: the monitoring (alignment) and the expropriation (entrenchment) effect of ownership concentration (Filatotchev, Jackson, \& Nakajima, 2013). In fact, dispersion of ownership makes controlling difficult and also contributes to creating potential free-riding problems. Predictions of the positive effect of ownership concentration on performance's firm are based on the monitoring effect. Accordingly, ownership concentration has a disciplinary effect on managers because it is easier for large shareholders to monitor managers (Shleifer \& Vishny, 1986). Thereby, from the agency theory, ownership concentration is regarded as the key and efficient component of corporate governance mechanism to reduce agency problems arising out of the separation of ownership and control (Balsmeier \& Czarnitzki, 2017; Nguyen, Locke, \& Reddy, 2015). Thus, a positive association between ownership concentration's ownership and performance's firm is expected. These expectations are essentially consistent with the monitoring or controlling hypothesis.

On the other hand, predictions of the negative impact of concentrated ownership on performance are based on the expropriation or entrenchment effect (Young, Peng, Ahlstrom, Bruton, \& Jiang, 2008). Based on this line of research, ownership concentration may facilitate the controlling of shareholders'extraction of private benefits at the expense of the wealth of minority shareholders (Filatotchev et al., 2013) thus increasing the expropriation effect which, in turn, conducts to the damaging of firm's performance. According to both effects mentioned above, some researchers have found a curvilinear association between ownership concentration and performance (Thomsen \& Pedersen, 2000; Tuschke \& Gerard Sanders, 2003). That is, when the ownership becomes highly concentrated, the association between these two variables becomes negative (expropriation effect). So, it is expected that:

H1: Ownership concentration has a significant relationship with financial performance.

\section{2- Dividend Policy and Firm Performance}

They are plethora of empirical researchs on dividend policies in the world at large. In effect, some authors have studied the determinants of dividend policies, why some others have investigated the influence of dividend policies on performance's firm in different sectors.

For instance, from the foreign scene, (Dogan \& Topal, 2014) tested the relation between dividend policies and financial performances in Istanbul Stock Exchange. The results of the analysis showed that dividend policies had an influence on companies' performances. Also, there was a positive and statistically meaningful association 
between the dividend payments and market-based performance indicator (Tobin's q). The study by Kajola et al. (2015) revealed that a proportionate change in dividend payout ratio resulted in a proportionate change in firm financial performance. In conclusion, the study demonstrated that dividend payout, which is a component of dividend policies affects significantly and positively firm performance. These studies are supported by (Farrukh, Irshad, Shams Khakwani, Ishaque, \& Ansari, 2017; M'rabet \& Boujjat, 2016))who examined the association between dividend policies and financial performance, the main findings indicated that dividend policies and total assets had a significant and positive association with firm performance.

H2: Return on the asset has a significant relationship with financial performance.

\section{3- Leverage and Firm Performance}

Leverage or financing refers to the extent to which companies make use of their money, borrowings to increase firm profitability. Also, leverage refers to the proportion of debt to equity in the capital structure of a company. Generally, this control varibale is measured by total liabilities to equity. The leverage decision is a significant managerial decision because it affects the shareholder's return and risk and the market value's firm (Omondi \& Muturi, 2013). According to (Alkhatib, 2012), leverage is viewed as a result of events that determines firms' source of financing to run the firm's business.

Studying the association between financial leverage and performance in previous literature has mixed findings. Firstly, financial leverage can negatively affect firm performance because leverage can be treated as a tool for indisciplining management. For instance, the findings of (Ahmed Sheikh \& Wang, 2013; Jeleel \& Olayiwola, 2017; Mireku, Mensah, \& Ogoe, 2014; Olokoyo, 2013) found a negative relationship between leverage and firm performance. In contrast, some research revealed a linear association. For example, (Ali, 2014) investigated the association between financial leverage and financial Performance evidence of listed chemical Pakistani firms. According to the agency theory, the fundamental idea behind positive or negative cost theory depends on the links between shareholders and managers, and those between debt-holders and shareholders (Jensen \& Meckling, 1976). Based on this perspective, the link is positive when the agency costs of equity between shareholders and managers, while it is negative when the agency costs of debt between shareholders and creditors.

H3: Leverage has a significant relationship with financial performance.

\section{4- Liquidity and Firm Performance}

Liquidity management is most essential for every company that means to pay current obligations on business, the payment obligations include operating and financial expenses that are short term but maturing long term debt. Liquidity ratios are used for liquidity management in the form of current ratio, quick ratio and Acid test ratio that greatly influence on profitability's company.

A lot of studies has already been conducted on the effect of financial leverage on firm profitability. For example, (Kaur \& Silky, 2013)and (Malik \& Ahmed, 2013) studied all the listed companies on the National Stock Exchange of India to analyze the influence of working capital management in terms of liquidity management on firm profitability. The revealed result is consistent with the trade-off theory that there is a negative association between the current ratio and return on assets (ROA). In the contrary case, (Alagathurai, 2013; Ben-Caleb, Olubukunola, \& Uwuigbe, 2013) in their studies founded that there is a significant positive association between quick ratio's liquidity and return on assets. Then, the studies revealed that there is a positive relationship between cash ratio and profitability. Also, (Zygmunt, 2013) conluded that increase in the growth of the cash conversion cycle of liquidity will increase the profitability of Polish IT firms. The research has revealed a positive association between ROA and growth of the inventory sale period, collection period \& account payables period. Moreover, the study showed by (Ismail, 2016) showed that liquidity current ratio has a significant positive relationship on firm profitability.

H4: Liquidity has a significant relationship with financial performance.

\section{5- Board size and Firm Performance}

In general, the board of directors size is a governance mechanism which refers to the total number of directors on the board. The latter comprises, in effect, executive as well as non-executive directors. Hence, the ideal board of directors size varies for each board. Basing on (Mohan \& Chandramohan, 2018), the majority of the research are oriented towards ascertaining the impact of board size which is an important dimension of corporate governance on firm performance. Some of these studies revealed an increase in the effectiveness of the company as the board of directors size grows. According to (Agyemang Badu \& Appiah, 2017) agency perspective describes the size of the board depicting the level of control exercised by management, while some authors suggested the opposite. In effect, a decrease in the effectiveness of the company as the board of directors size grows.

H5: Board size has a significant relationship with financial performance. 


\section{6- Firm size and Firm Performance}

According to (Hirdinis, 2019) firm size is a crucial determinant of the profits of the firm. The assets owned by the firm indicate whether it is classified as a large or big firm or not. Generally, firm size is measured using Ln total assets. Researches on the effect of firm size on firm performance have generated mixed results ranging from those supporting a positive relationship among these variables to those opposing it. Basing on (Aduralere Opeyemi, 2019)all the study in Nigeria showed that there is a positive relationship between company size and company's performance. However, other research found a negative or weak negative association between size and firm performance. For instance (Močnik \& Širec, 2015)and (Banchuenvijit \& Pariyanont, 2012) shed light on the factors like firm size, that determines the profitability of a developing company using a sample of 782 Slovenian fast-growing companies. The result from the findings showed a negative association between firm company and profitability.

H6: Firm Size has a significant relationship with financial performance.

\section{7-Tangibility and Firm Performance}

Tangibility is considered to be the major determinant of a company's performance. The most common stated in the literature favours a positive association between asset tangibility and performance. For instance, (MacKie-Mason, 1990) argumed that a company with high fraction of tangible assets is the asset base made the debt choice more likely and influences the performance'company. Also, (Akintoye, 2008)concludes that a company which retained large investments was tangible assets will have smaller costs of financial distress than a company that relied on intangible assets.Finally, (Kothari, Laguerre, \& Leone, 2002) concluded that when R\&D expense increases, the future earning'company will increase as well. Then the relation between asset tangibility and company performance is expected to be positive.

H7: Tangibility has a significant relationship with financial performance.

\section{3-Data and Methodology}

The objectives of the current study are to investigate the relationship between ownership concentration and dividend policy on firms financial performance. For this purpose the data has been collected from the annual reports of chemical sector listed at Pakistan Stock Exchange (PSE), during the time span of 2012-2017. In PSE, there are 42 firms listed in chemical sector but this study has adopted 26 firms due to the inconvenient and nonavalability of data.

\section{1-Variables}

The current study used the following dependent, independent and control variables:

Table 1: Description of variables

\begin{tabular}{|l|l|l|}
\hline Variables & Label & Description \\
\hline Return on assets & ROA & Earnings after tax divided by total assets \\
\hline Ownership Concentration & OWNR & Percentage of equity holds by top 5 substantial shareholders. \\
\hline Dividend Policy & DP & Dividend paid divided by net income. \\
\hline Leverage & LEV & Total debt divided by total assets. \\
\hline Liquidity & LIQ & Current liabilities divided by total liabilities. \\
\hline Board size & BSZ & log of the number of board of directors \\
\hline Firm size & FSZ & Natural logarithm of total assets. \\
\hline Tangibility & TAN & Fixed assets divided by total assets. \\
\hline
\end{tabular}

\subsection{1- Dependent Variable}

Firm performance is measured through return on assets (ROA) (Briones \& Chang, 2017). It is calculated by earnings before interest and tax divided by total assets (Murtaza \& Azam, 2019; Riaz, 2015); which shows that how much a firm earned by investment of the assets and how the managers use effectively the investors fund (Vătavu, 2015) or in other words it generates an idea about how efficient management using its assets to generate large earnings (Nawaz \& Haniffa, 2017).

\subsection{2- Independent Variable}

The current study analyzed ownership concentration (OWNR) and dividend policy are independent variable. OWNR is calculated as a percentage of equity held by the top 5 substantial shareholders of the firm (Murtaza \& Azam, 2019; Paramanantham, Ting, \& Kweh, 2018; Xinyuan, Nan, \& Yufei, 2017). While dividend policy (DP) is calculated as cash dividend divided by net income (Maladjian \& Khoury, 2014).

\subsection{3- Control Variable}

Following control are used in this study. Liquidity (LIQ) is measured as the number of current liabilities/ total liabilities (Ahmed Sheikh \& Wang, 2011; Goh, Tai, Rasli, Tan, \& Zakuan, 2018). Tangibility (TAN) is calculated by the amount of fixed assets divided by total assets (Goh et al., 2018; Sheikh \& Qureshi, 2017). 
Board size (BSZ), as measured by the log of number of board of directors (Abor, 2007; Kajananthan, 2012; Khawaja, Bhatti, Ashraf, \& Henry, 2018; Murtaza \& Azam, 2019). Whereas leverage (LEV) is calculated as total debt divided by total assets (Ilmas, Tahir, \& Asrar-ul-Haq, 2018) and firm size (FSZ) is calculated by taking the natural logarithm of total assets (Abdullah, 2005; Murtaza \& Azam, 2019).

\section{2- Empirical Model}

In order to examine the role of ownership concentration and dividend policy on firm performance, we used the following model specification:

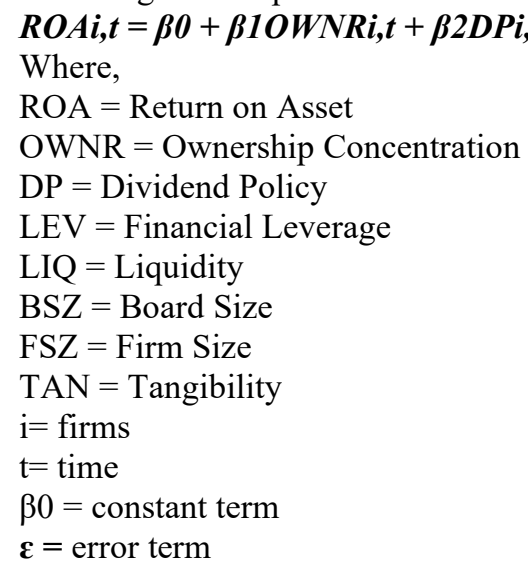

\section{4- Empirical Results}

\section{1- Descriptive Statistics}

Table 2: Descriptive Statistics

\begin{tabular}{|l|l|l|l|l|l|}
\hline Variable & Obs & Mean & Std. Dev & Min & Max \\
\hline ROA & 156 & 0.088 & 0.233 & -2.295 & 0.465 \\
\hline OWNR & 156 & 0.625 & 0.238 & 0.119 & 0.908 \\
\hline DP & 156 & 0.233 & 0.698 & -1.852 & 1.817 \\
\hline BSZ & 156 & 2.085 & 0.233 & 1.386 & 2.565 \\
\hline FSZ & 156 & 14.382 & 2.02 & 7.979 & 18.818 \\
\hline LEV & 156 & 1.777 & 15.885 & 0.119 & 198.866 \\
\hline LIQ & 156 & 2.026 & 4.486 & 0.007 & 45.31 \\
\hline TAN & 156 & 0.535 & 0.233 & 0.018 & 1 \\
\hline
\end{tabular}

Table 2, explained the results of descriptive statistics for all dependent and explanatory variables used in this study. Total number of observations used in this study are 156 . The mean value of ROA is 0.08 with minimum value of $-2,295$ and maximum of 0.465 . The average of ownership is $62 \%$ having minimum of 0.119 and maximum of 0.908 . The average of DP is $23 \%$ having min and max of -1.852 and 1.817 respectively. The average value of BSZ is $2.08, \mathrm{FSZ}$ is 14.38 , LEV is 1.77 , LIQ is 2.12 and TAN with 0.535 .

\section{2- Correlation}

Correlation table is used to measure the relationship between dependent and independent variables. Results of table 3 illustrate the association between dependent and explanatory variables of the current study. All variables have positive relationship with ROA except LEV and TAN that have a negative association with ROA. According to (Gujarati, 2009) highly correlation of independent will create the multicollinearity issue. Further, the multicollinearity is also measured by variance inflation factor (VIF) as shown in table 4. All the VIF values are less than 10, which depicts that there is no multicollinearity issue in the model (Wooldridge, 2015).

\begin{tabular}{|c|c|c|c|c|c|c|c|c|}
\hline Variables & (1) & (2) & (3) & (4) & (5) & (6) & (7) & (8) \\
\hline ROA & 1.000 & & & & & & & \\
\hline OWNR & 0.023 & 1.000 & & & & & & \\
\hline DP & 0.290 & -0.072 & 1.000 & & & & & \\
\hline BSZ & 0.231 & -0.288 & 0.170 & 1.000 & & & & \\
\hline FSZ & 0.283 & -0.092 & 0.076 & 0.275 & 1.000 & & & \\
\hline LEV & -0.832 & 0.086 & -0.148 & -0.050 & -0.201 & 1.000 & & \\
\hline LIQ & 0.194 & 0.160 & 0.043 & -0.051 & 0.019 & -0.023 & 1.000 & \\
\hline TAN & -0.371 & -0.157 & -0.318 & -0.019 & 0.283 & 0.169 & -0.308 & 1.000 \\
\hline
\end{tabular}


Table 4: Multicollinearity

\begin{tabular}{|l|l|l|}
\hline Variables & VIF & 1/VIF \\
\hline TAN & 1.52 & 0.656319 \\
\hline FSZ & 1.33 & 0.750078 \\
\hline BSZ & 1.22 & 0.820692 \\
\hline DP & 1.19 & 0.842522 \\
\hline OWNR & 1.16 & 0.86311 \\
\hline LIQ & 1.15 & 0.869189 \\
\hline LEV & 1.13 & 0.885262 \\
\hline Mean VIF & 1.24 & \\
\hline
\end{tabular}

\section{3- Panel Regression Analysis}

Before estimating the regression analysis, we have tested some basic assumptions such as heteroskedasticity, serial correlation, VIF and Hausman test, in order to reduce the spurious results from the data.

Table 5: Breusch-Pagan test for heteroskedasticity

$\operatorname{chi} 2(1)=1.16$

Prob $>$ chi $2=0.2820$

The current study have used Wooldridge test to measure the autocorrelation problem in data. In this regards, the $\mathrm{p}$-value is 0.2241 which is greater than $5 \%$. It means that there is absence of serial correlation in our data.

Table 6: Wooldridge test for autocorrelation

$$
\mathrm{F}(1, \quad 25)=1.554
$$

Prob $>\mathrm{F}=0.2241$

Hausman test is used to determine between random effects model and fixed effects model of regression (Griffiths, Hill, \& Lim, 2008). This specific model is used to measure that which model is to be fit between the fixed effect method and random effect model. The null hypothesis states that random effect model is better to use. So, the results of table 7, depicts that random effect model is better to use in this study.

Table 7: The Hausman Test

\begin{tabular}{lll}
\hline Research model & Prob $>$ chi2 & Test result \\
\hline ROA & 0.4262 & Random effect method \\
\hline
\end{tabular}

Table 8, explained the results of random effect "GLS model" of regression. The regression results reveals that $\mathrm{OWN}$ has a significant positive relationship with ROA at $1 \%$. Increase in ownership concentration is lead with higher firm performance (Perrini, Rossi, \& Rovetta, 2008; D. A. Singh \& Gaur, 2009; Thomsen \& Pedersen, 2000). Some findings reveal that ownership concentration is negatively related with firm performance (Bektas \& Kaymak, 2009; Khanchel El Mehdi, 2007; Veprauskaite \& Adams, 2013). While some studies describes that there is no relationship between OWN and firm performance (Sacristán-Navarro, Gómez-Ansón, \& CabezaGarcía, 2011; Tuschke \& Gerard Sanders, 2003). DP also has a significant positive effect with firm performance at 5\%. These findings are consistent with some previous studies (Farrukh et al., 2017; Tahir, Sohail, Qayyam, \& Mumtaz, 2016) that explained that firms may decrease agency cost by paying dividend. This support to the dividend relevance theory (Gordon, 1963; Walter, 1963). BSZ is significant positively influenced on firm performance at 1\% (Dalton, Daily, Johnson, \& Ellstrand, 1999; Lipton \& Lorsch, 1992; S. Singh, Tabassum, Darwish, \& Batsakis, 2018). Because the larger shareholders build many opportunities for firms as well as they also reduce the conflicts among multiple groups of interest. These results are against to the studies of (Chiang \& Lin, 2007; Nguyen, Locke, \& Reddy, 2014). FSZ is also significant positively related with firm performance which depicts that smaller firms increase market performance and larger firms enhance accounting performance. In other words, smaller firms resolve their issues quickly, while larger firms face many issues. LIQ also has a positive significant relationship on ROA. Whereas, LEV is negatively influenced (Campbell \& Mínguez-Vera, 2008 ) and TAN is also negatively related with firm performance at the level of $1 \%$. High degree of leverage also increase the risk of bankruptcy. R-square shows the degree of variation in firm performance due to all explanatory variables used in the current study. So, here the value of R-square is $83 \%$ and wald chi 2 value is 761.01 that shows the significance of model. 
Table 8: Generalized Least Squares Model

\begin{tabular}{|c|c|c|c|c|}
\hline ROA & Coef. & Std. Err. & $\mathbf{Z}$ & $\mathbf{P}>\mathbf{Z}$ \\
\hline OWN & 0.104987 & 0.034728 & 3.02 & $0.003 * * *$ \\
\hline DP & 0.02485 & 0.011993 & 2.07 & $0.038 * *$ \\
\hline BSZ & 0.172085 & 0.036388 & 4.73 & $0.000 * * *$ \\
\hline FSZ & 0.01681 & 0.004391 & 3.83 & $0.000 * * * *$ \\
\hline LEV & -0.01105 & 0.000514 & -21.5 & $0.000 * * *$ \\
\hline LIQ & 0.005005 & 0.001837 & 2.73 & $0.006^{* * *}$ \\
\hline TAN & -0.21039 & 0.040643 & -5.18 & $0.000 * * *$ \\
\hline _CONS & -0.46165 & 0.090855 & -5.08 & $0.000 * * *$ \\
\hline \multicolumn{4}{|c|}{$\overline{\text { Observations }}$} & 156 \\
\hline \multicolumn{4}{|c|}{ R-squared } & 0.83 \\
\hline \multicolumn{4}{|c|}{ Number of groups } & 26 \\
\hline \multicolumn{4}{|c|}{ Wald chi2(7) } & 761.01 \\
\hline \multicolumn{4}{|c|}{ Prob > chi2 } & 0.000 \\
\hline
\end{tabular}

\section{5-Conclusion}

The main aim of the current study is to measure the effect of ownership concentration and dividend policy on firm financial performance. This study used panel data for the period of 2012-2017 for Chemical firms listed at Karachi Stock Exchange of Pakistan. After employing panel data analysis, the findings reveal that ownership concentration has a significant positive association with firm financial performance. This stated that larger shareholders have a right to minimize the agency cost between managers and shareholders. They also monitor the team very effectively and efficiently. They also monitor the team very effectively and efficiently. The presence of a controlling shareholder acts as a governance mechanism to discipline the leaders. Dividend policy has a significant positive relationship with firm performance. Increase in dividend improve firm performance. Tangibility have a significant negative relationship with financial leverage. Board size also has a significant positive impact on firm performance. Larger shareholders solve the conflicts of interest among managers and shareholders.

\section{1-Policy Implications/ Recommendations}

The findings of the current study are beneficial for practitioners, policymakers and stakeholders for understanding the importance of corporate governance mechanism. These results can be helpful to the regulatory bodies for incorporating the new policies of corporate governance in emerging markets. Further, the results provide better output and generally, firms may require to improve the importance and strengthen of corporate governance mechanism.

\section{2-Limitations}

While the findings of the current study are significant, stable and also have highlighted an extensive body of literature towards the relationship between ownership structure, dividend policy and firm performance, but it also has some limitations and weaknesses in some aspects. First and foremost, this study has used data of small time periods and a limited number of observations due to manually collection of corporate governance data. As this one is the first study conducted to examine the linkage between ownership structure, dividend policy and firm performance in Pakistan. Therefore, the results cannot compare to any other study that examines the insight of Pakistan firms. Second, this sample of the study is limited to chemical sector firms of KSE-100 index, also excluded the other sectors and financial firms. So, the results are not encountered all the public listed companies of Pakistan. Third, this research is mainly focused on the single country data, by considering the relationship between ownership structure and firm performance of Pakistan firms listed at KSE-100 index, the findings may not be generalized to emerging markets of other countries.

\section{3-Future call}

In the future, it would be interesting to investigate the linkage between ownership structure, dividend policy and firm performance in different sectors and or especially in developing countries. Future researchers may carry out different other variables of ownership such as family ownership, individual and institutional ownership and also can enhance the sample size of firms.

\section{References}

Abdullah, A. K. (2005). Capital structure and debt maturity: evidence from listed companies in Saudi Arabia. 
Journal of Business and Economics.

Abor, J. (2007). Capital structure and financing of Smes: empirical evidence from Ghana and South Africa. Stellenbosch: Stellenbosch University.

Aduralere Opeyemi, O. (2019). The Impact of Firm Size on Firms Performance in Nigeria: A Comparative Study of Selected Firms in the Building Industry in Nigeria. Asian Development Policy Review, 7(1), 1-11.

Agyemang Badu, E., \& Appiah, K. (2017). The Impact of Corporate Board Size on Firm Performance: Evidence from Ghana and Nigeria.

Ahmed Sheikh, N., \& Wang, Z. (2011). Determinants of capital structure: An empirical study of firms in manufacturing industry of Pakistan. Managerial Finance, 37(2), 117-133.

Ahmed Sheikh, N., \& Wang, Z. (2013). The impact of capital structure on performance: An empirical study of non-financial listed firms in Pakistan. International Journal of Commerce and Management, 23(4), 354-368.

Akintoye, I. R. (2008). Effect of capital structure on firms' performance: the Nigerian experience. European Journal of Economics, Finance and Administrative Sciences, 10(1), 233-243.

Al-Nawaiseh, M. (2013). Dividend policy and ownership structure: an applied study on industrial companies in Amman Stock Exchange. Journal of Management Research, 5(2), 83.

Alagathurai, A. (2013). A nexus between liquidity \& profitability: a study of trading companies in Sri Lanka. Ajanthan, A.(2013). A Nexus Between Liquidity \& Profitability: A Study Of Trading Companies In Sri Lanka. European Journal of Business and Management, 5(7), 221-237.

Ali, M. (2014). Relationship between Financial Leverage and Financial Performance (Evidence of Listed Chemical Companies of Pakistan). Research Journal of Finance and Accounting, 5(23), 46-56.

Alkhatib, K. (2012). The determinants of leverage of listed companies. International Journal of Business and Social Science, 3(24).

Aslam, E., Haron, R., \& Tahir, M. N. (2019). How director remuneration impacts firm performance: An empirical analysis of executive director remuneration in Pakistan. Borsa Istanbul Review.

Baber, W. R., Liang, L., \& Zhu, Z. (2012). Associations between internal and external corporate governance characteristics: Implications for investigating financial accounting restatements. Accounting Horizons, 26(2), 219-237.

Balsmeier, B., \& Czarnitzki, D. (2017). Ownership concentration, institutional development and firm performance in Central and Eastern Europe. Managerial and Decision Economics, 38(2), 178-192.

Banchuenvijit, W., \& Pariyanont, Y. (2012). Factors Affecting the Percentage Change in Stock Prices of Listed Companies on the Stock Exchange of Thailand in the Health Sector. University of the Thai Chamber of Commerce Journal, 32(1).

Bebchuk, L., Cohen, A., \& Ferrell, A. (2008). What matters in corporate governance? The review of financial studies, 22(2), 783-827.

Bektas, E., \& Kaymak, T. (2009). Governance mechanisms and ownership in an emerging market: The case of Turkish banks. Emerging Markets Finance and Trade, 45(6), 20-32.

Ben-Caleb, E., Olubukunola, U., \& Uwuigbe, U. (2013). Liquidity management and profitability of manufacturing companies in Nigeria. IOSR Journal of Business and Management, 9(1), 13-21.

Bhagat, S., \& Bolton, B. (2008). Corporate governance and firm performance. Journal of corporate finance, 14(3), 257-273

Briones, O., \& Chang, M. (2017). Capital Structure Determinants Influence: A Comparative Study. Paper presented at the Proceedings of International Academic Conferences.

Bryson, A., Forth, J., \& Zhou, M. (2014). Same or different? The CEO labour market in China's public listed companies. The Economic Journal, 124(574), F90-F108.

Campbell, K., \& Mínguez-Vera, A. (2008). Gender diversity in the boardroom and firm financial performance. Journal of Business Ethics, 83(3), 435-451.

Chiang, M. H., \& Lin, J. H. (2007). The Relationship between Corporate Governance and Firm Productivity: evidence from Taiwan's manufacturing firms. Corporate Governance: An International Review, 15(5), 768779.

Cremers, M., \& Ferrell, A. (2014). Thirty years of shareholder rights and firm value. The journal of finance, 69(3), 1167-1196.

Cuñat, V., Gine, M., \& Guadalupe, M. (2012). The vote is cast: The effect of corporate governance on shareholder value. The journal of finance, 67(5), 1943-1977.

Dalton, D. R., Daily, C. M., Johnson, J. L., \& Ellstrand, A. E. (1999). Number of directors and financial performance: A meta-analysis. Academy of Management Journal, 42(6), 674-686.

Dogan, M., \& Topal, Y. (2014). The influence of dividend payments on company performance: The Case of Istanbul Stock Exchange (BIST). European Journal of Business and Management, 6(3), 189-197.

Farrukh, K., Irshad, S., Shams Khakwani, M., Ishaque, S., \& Ansari, N. Y. (2017). Impact of dividend policy on shareholders wealth and firm performance in Pakistan. Cogent Business \& Management, 4(1), 1408208. 
Filatotchev, I., Jackson, G., \& Nakajima, C. (2013). Corporate governance and national institutions: A review and emerging research agenda. Asia Pacific Journal of Management, 30(4), 965-986.

$\mathrm{Fu}, \mathrm{Y}$. (2019). The value of corporate governance: Evidence from the Chinese anti-corruption campaign. The North American Journal of Economics and Finance, 47, 461-476.

Gillan, S. L. (2006). Recent developments in corporate governance: An overview: Elsevier.

Giroud, X., \& Mueller, H. M. (2011). Corporate governance, product market competition, and equity prices. The journal of finance, 66(2), 563-600.

Goh, C. F., Tai, W. Y., Rasli, A., Tan, O. K., \& Zakuan, N. (2018). The Determinants of Capital Structure: Evidence from Malaysian Companies. International Journal of Supply Chain Management, 7(3), 225-230.

Gompers, P., Ishii, J., \& Metrick, A. (2003). Corporate governance and equity prices. The quarterly journal of economics, 118(1), 107-156.

Gordon, M. J. (1963). Optimal investment and financing policy. The journal of finance, 18(2), 264-272.

Griffiths, W. E., Hill, R. C., \& Lim, G. C. (2008). Using EViews for principles of econometrics.

Gujarati, D. N. (2009). Basic econometrics: Tata McGraw-Hill Education.

Hirdinis, M. (2019). Capital structure and firm size on firm value moderated by profitability.

Holmstrom, B. (1979). Moral hazard and observability. Bell journal of Economics, 10(1), 74-91.

Ilmas, F., Tahir, S., \& Asrar-ul-Haq, M. (2018). Ownership structure and debt structure as determinants of discretionary accruals: An empirical study of Pakistan. Cogent Economics \& Finance, 6(1), 1439254.

Ismail, R. (2016). Impact of liquidity management on profitability of Pakistani firms: A case of KSE-100 Index. International Journal of Innovation and Applied Studies, 14(2), 304.

Jeleel, A., \& Olayiwola, B. (2017). Effect of leverage on firm performance in nigeria: A case of listed chemicals and paints firms in Nigeria. Global Journal of Management And Business Research.

Jensen, M. C. (1986). Agency costs of free cash flow, corporate finance, and takeovers. The American economic review, 76(2), 323-329.

Jensen, M. C. (1993). The modern industrial revolution, exit, and the failure of internal control systems. The journal of finance, 48(3), 831-880.

Jensen, M. C., \& Meckling, W. H. (1976). Theory of the firm: Managerial behavior, agency costs and ownership structure. Journal of financial economics, 3(4), 305-360.

Kajananthan, R. (2012). Effect of corporate governance on capital structure: case of the Srilankan listed manufacturing companies. Researchers World, 3(4), 63.

Kaur, S., \& Silky, J. (2013). A study on liquidity and profitability of selected indian cement companies: a regression modeling approach. International Journal of Economics, Commerce and Management, 1(1), 124.

Kazi, A. G., Arain, M. A., \& Sahetiya, P. D. (2018). Corporate Governance and Firm Performance Nexus: A Case of Cement Industry of Pakistan. International Journal of Entrepreneurial Research, 1(1), 1-6.

Khanchel El Mehdi, I. (2007). Empirical evidence on corporate governance and corporate performance in Tunisia. Corporate Governance: An International Review, 15(6), 1429-1441.

Khawaja, M., Bhatti, I., Ashraf, D., \& Henry, D. (2018). The Role of Ownership and Governance Structure in Raising Capital: An International Study. 9th Conference on Financial Markets and Corporate Governance (FMCG) 2018. Available at SSRN: https://ssrn.com/abstract $=3102108$ or http://dx.doi.org/10.2139/ssrn.3102108

Kothari, S., Laguerre, T. E., \& Leone, A. J. (2002). Capitalization versus expensing: Evidence on the uncertainty of future earnings from capital expenditures versus R\&D outlays. Review of accounting Studies, 7(4), 355382.

La Porta, R., Lopez-de-Silanes, F., Shleifer, A., \& Vishny, R. W. (1997). Legal determinants of external finance. The journal of finance, 52(3), 1131-1150.

Lipton, M., \& Lorsch, J. W. (1992). A modest proposal for improved corporate governance. The business lawyer, $59-77$.

M'rabet, R., \& Boujjat, W. (2016). The relationship between dividend payments and firm performance: A study of listed companies in Morocco. European scientific journal, 12(4).

MacKie-Mason, J. K. (1990). Do taxes affect corporate financing decisions? The journal of finance, 45(5), 14711493.

Maladjian, C., \& Khoury, R. E. (2014). Determinants of the dividend policy: an empirical study on the Lebanese listed banks. International Journal of Economics and Finance, 6(4), 240-256.

Malik, Q. A., \& Ahmed, S. F. (2013). Idiosyncratic effect of liquidity management strategies on corporate performance valuation-A study of Chemical Industry. World Applied Sciences Journal, 28(1), 114-119.

Mireku, K., Mensah, S., \& Ogoe, E. (2014). The relationship between capital structure measures and financial performance: Evidence from Ghana. International Journal of Business and Management, 9(6), 151. 
Močnik, D., \& Širec, K. (2015). Determinants of a fast-growing firm's profits: Empirical evidence for Slovenia. Annals of the Alexandru Ioan Cuza University-Economics, 62(1), 37-54.

Mohan, A., \& Chandramohan, S. (2018). Impact of corporate governance on firm performance: empirical evidence from India. IMPACT: International Journal of Research in Humanities, Arts and Literature (IMPACT: IJRHAL) ISSN (P), 2347-4564.

Murtaza, S., \& Azam, I. (2019). The Relationship between Ownership Structure and Capital Structure. SEISENSE Journal of Management, 2(4), 51-64.

Nawaz, T., \& Haniffa, R. (2017). Determinants of financial performance of Islamic banks: An intellectual capital perspective. Journal of Islamic Accounting and Business Research, 8(2), 130-142.

Nguyen, T., Locke, S., \& Reddy, K. (2014). A dynamic estimation of governance structures and financial performance for Singaporean companies. Economic Modelling, 40, 1-11.

Nguyen, T., Locke, S., \& Reddy, K. (2015). Ownership concentration and corporate performance from a dynamic perspective: Does national governance quality matter? International Review of Financial Analysis, $41,148-161$

Olokoyo, F. O. (2013). Capital structure and corporate performance of Nigerian quoted firms: A panel data approach. African Development Review, 25(3), 358-369.

Omondi, M. M., \& Muturi, W. (2013). Factors affecting the financial performance of listed companies at the Nairobi Securities Exchange in Kenya. Research Journal of Finance and Accounting, 4(15), 99-104.

Paramanantham, N. S., Ting, I. W. K., \& Kweh, Q. L. (2018). Ownership Concentration and Debt Structure: Evidence from Top 100 PLCs in Malaysia. Institutions and Economies.Available at: $<$ https://ijie.um.edu.my/article/view/11946>.

Perrini, F., Rossi, G., \& Rovetta, B. (2008). Does ownership structure affect performance? Evidence from the Italian market. Corporate Governance: An International Review, 16(4), 312-325.

Riaz, S. (2015). Impact of Capital Structure on Firm's Financial Performance: An Analysis of Chemical Sector of Pakistan. Journal of Poverty, Investment and Development, 12(1).

Ross, S. A. (1973). The economic theory of agency: The principal's problem. The American economic review, 63(2), 134-139.

Sacristán-Navarro, M., Gómez-Ansón, S., \& Cabeza-García, L. (2011). Large shareholders' combinations in family firms: Prevalence and performance effects. Journal of Family Business Strategy, 2(2), 101-112.

Sáez, M., \& Gutiérrez, M. (2015). Dividend policy with controlling shareholders. Theoretical Inquiries in Law, 16(1), 107-130.

Shah, M., Xiao, Z. P., \& Quresh, S. (2019). Complex Pyramid Structure, Judicial Efficiency and Firm Performance A Comparative Analysis of Chinese and Pakistani Listed Companies. Shakir, Complex Pyramid Structure, Judicial Efficiency and Firm Performance A Comparative Analysis of Chinese and Pakistani Listed Companies (January 20, 2019).

Sheikh, N. A., \& Qureshi, M. A. (2017). Determinants of capital structure of Islamic and conventional commercial banks: Evidence from Pakistan. International Journal of Islamic and Middle Eastern Finance and Management, 10(1), 24-41.

Shleifer, A., \& Vishny, R. W. (1986). Large shareholders and corporate control. Journal of political economy, 94(3, Part 1), 461-488.

Singh, D. A., \& Gaur, A. S. (2009). Business group affiliation, firm governance, and firm performance: Evidence from China and India. Corporate Governance: An International Review, 17(4), 411-425.

Singh, S., Tabassum, N., Darwish, T. K., \& Batsakis, G. (2018). Corporate governance and Tobin's Q as a measure of organizational performance. British Journal of management, 29(1), 171-190.

Sun, S. L., Zhao, X., \& Yang, H. (2010). Executive compensation in Asia: A critical review and outlook. Asia Pacific Journal of Management, 27(4), 775-802.

Tahir, S. H., Sohail, S., Qayyam, I., \& Mumtaz, K. (2016). Effect of corporate governance index on dividend policy: An investigation of textile industry of Pakistan. Journal of Economic and Social Development, 3(1), 139.

Thomsen, S., \& Pedersen, T. (2000). Ownership structure and economic performance in the largest European companies. Strategic management journal, 21(6), 689-705.

Ting, I. W. K., Kweh, Q. L., \& Somosundaram, K. (2017). Ownership concentration, dividend payout and firm performance: The case of Malaysia. Malaysian Journal of Economic Studies, 54(2), 269-280.

Tuschke, A., \& Gerard Sanders, W. (2003). Antecedents and consequences of corporate governance reform: The case of Germany. Strategic management journal, 24(7), 631-649.

Van Essen, M., van Oosterhout, J. H., \& Carney, M. (2012). Corporate boards and the performance of Asian firms: A meta-analysis. Asia Pacific Journal of Management, 29(4), 873-905.

Vătavu, S. (2015). The impact of capital structure on financial performance in Romanian listed companies. Procedia Economics and Finance, 32, 1314-1322. 
Veprauskaite, E., \& Adams, M. (2013). Do powerful chief executives influence the financial performance of UK firms? The British Accounting Review, 45(3), 229-241.

Walter, J. E. (1963). Dividend policy: its influence on the value of the enterprise. The journal of finance, 18(2), 280-291.

Warrad, L., Abed, S., Khriasat, O., \& Al-Sheikh, I. (2012). The effect of ownership structure on dividend payout policy: Evidence from Jordanian context. International Journal of Economics and Finance, 4(2), 187-195.

Weir, C., Laing, D., \& McKnight, P. J. (2002). Internal and external governance mechanisms: their impact on the performance of large UK public companies. Journal of Business Finance \& Accounting, 29(5-6), 579-611.

Wooldridge, J. M. (2015). Introductory econometrics: A modern approach: Nelson Education.

Xinyuan, Z., Nan, B., \& Yufei, Z. (2017). Ownership Concentration, Financial Leverage and Inefficient Investment-evidence from Chinese A-share Market. Applied Finance and Accounting, 3(2), 70-75.

Yermack, D. (1996). Higher market valuation of companies with a small board of directors. Journal of financial economics, 40(2), 185-211.

Young, M. N., Peng, M. W., Ahlstrom, D., Bruton, G. D., \& Jiang, Y. (2008). Corporate governance in emerging economies: A review of the principal-principal perspective. Journal of management studies, 45(1), 196-220.

Zygmunt, J. (2013). Does liquidity impact on profitability. Paper presented at the Conference of informatics and management sciences, March. 